\title{
Floristic and Forest Inventory of Santa Catarina: species of evergreen rainforest
}

Inventário Florístico Florestal de Santa Catarina: espécies da floresta pluvial subtropical

André Luís de Gasper ${ }^{1,5}$, Alexandre Uhlmann ${ }^{4}$, Lucia Sevegnani ${ }^{1}$, Leila Meyer ${ }^{3}$, Débora Vanessa Lingner ${ }^{3}$, Marcio Verdi ${ }^{3}$, Anita Stival-Santos ${ }^{3}$, Marcos Sobral $^{2} \&$ Alexander Christian Vibrans ${ }^{3}$

\begin{abstract}
This study presents the list of species of Evergreen Rainforest in Santa Catarina, based on 202 sample units established by the Floristic and Forest Inventory of Santa Catarina, in order to study the tree/shrub component and regeneration in addition to a floristic survey outside the sample units. We recorded 1,473 species: three gymnosperms and 1,470 angiosperms, that totalize 19\% of all species quoted for this Brazilian forest type. The most species-rich families were Orchidaceae (143 species), Myrtaceae (142), Asteraceae (98), Melastomataceae (86), Fabaceae (78), Rubiaceae (65), Solanaceae (61), Bromeliaceae (57), Piperaceae (56), and Lauraceae (52). Among them are eight species listed in the Official List of Endangered Species of the Brazilian Flora: Aechmea blumenavii, Araucaria angustifolia, Billbergia alfonsijoannis, Euterpe edulis, Heliconia farinosa, Ocotea catharinensis, O. odorifera and, O. porosa.
\end{abstract}

Key words: Atlantic Forest, Dense Ombrophylous Forest, richness, threatened species.

\section{Resumo}

O presente trabalho objetivou apresentar a lista de espécies da floresta pluvial subtropical (Floresta Ombrófila Densa) em Santa Catarina, com base em 202 unidades amostrais implantadas pelo Inventário Florístico Florestal de Santa Catarina para estudo do componente arbóreo-arbustivo e da regeneração, além de coletas florísticas externas às unidades amostrais. Foram registradas 1.473 espécies, 19,0\% das espécies citadas para esta tipologia florestal no Brasil, dentre estas três gimnospermas e 1.470 angiospermas. As famílias mais ricas em espécies foram: Orchidaceae (143 espécies), Myrtaceae (142), Asteraceae (98), Melastomataceae (86), Fabaceae (78), Rubiaceae (65), Solanaceae (61), Bromeliaceae (57), Piperaceae (56) e Lauraceae (52). Entre as espécies registradas, oito constam na Lista Oficial das Espécies da Flora Brasileira Ameaçadas de Extinção: Aechmea blumenavii, Araucaria angustifolia, Billbergia alfonsijoannis, Euterpe edulis, Heliconia farinosa, Ocotea catharinensis, O. odorifera e O. porosa.

Palavras-chave: Floresta Atlântica, Floresta Ombrófila Densa, riqueza, espécies ameaçadas.

\section{Introduction}

The most diverse forest type of the Atlantic Forest domain is the Evergreen Rainforest (Joly et al. 1999). In Santa Catarina (SC) state it occurs along the coastal mountain range, extending up to $200 \mathrm{~km}$ eastward and spanning from sea-level to
$1,000 \mathrm{~m}$ alt. It is influenced by subtropical climatic conditions such as high temperatures and high precipitation evenly distributed throughout the year, but it also experiences frost occasionally due to polar cold fronts during the winter (OliveiraFilho et al. 2013). The Evergreen Rainforest (or Dense Ombrophilous Forest sensu IBGE 1992)

\footnotetext{
${ }^{1}$ Universidade Regional de Blumenau, Herbário Dr. Roberto Miguel Klein (FURB), Depto. Ciências Naturais, R. Antônio da Veiga 140, 89012-900, Victor Konder, Blumenau, SC, Brazil.

${ }^{2}$ Universidade Federal de São João Del-Rei, Praça Frei Orlando 170, 36307-352, São João Del-Rei, MG, Brazil.

${ }^{3}$ Universidade Regional de Blumenau, Depto. Engenharia Florestal, R. Antônio da Veiga 140, 89012-900, Victor Konder, Blumenau, SC, Brazil.

${ }^{4}$ Embrapa Florestas, Est. da Ribeira, km 111, C.P. 319, 83411-000, Colombo, PR, Brazil.

${ }^{5}$ Author for correspondence: algasper@gmail.com
} 
originally covered around $27,555 \mathrm{~km}^{2}$ of SC territory; at present, the forest cover has decreased to $12,619 \mathrm{~km}^{2}$, or $40 \%$ Santa Catarina (Vibrans et al. 2013a). Although reduced and fragmented, it is still the richest and most exuberant forest type of the Atlantic Forest, comprising various life forms, in particular epiphytes (Klein 1978; Leite \& Klein 1990). Its high biological diversity is associated with the great environmental heterogeneity related to latitudinal and altitudinal distribution, geological diversity, and geomorphological diversity (e.g. the Serra do Mar and Serra Geral - see Martinelli 2007), which provides different site conditions of soil, and climate that influenced the different migration routes (Morellato 2000; Oliveira-Filho \& Fontes 2000; Leite 2002; Waechter 2002).

The Evergreen Rainforest is the most wellknown forest type in the state of Santa Catarina in regard to species diversity. This is due primarily to botanists Roberto Miguel Klein and Raulino Reitz, who in the mid-twentieth century conducted important research to identify, classify, and describe the vegetation (Veloso \& Klein 1957, 1959, 1961, 1963, 1968a, 1968b; Reitz 1965; Klein et al. 1978; Klein 1979, 1980). The biggest floristic list of Evergreen Rainforest was made by Klein $(1979,1980)$, who studied the Itajaí-Açu watershed, where he found approximately 2,000 species of vascular plants. More recently, several studies have described and analyzed species composition in Evergreen Rainforest in SC (e.g. Citadini-Zanette et al. 1997; Falkenberg 1999; Negrelle 2006; Klein et al. 2007; Colonetti et al. 2009; Neves \& Zanin 2011). However, despite recent efforts, large-scale studies carried out with comparable sampling design are still scarce. Only recently the assessments of the Floristic and Forest Inventory of Santa Catarina (IFFSC, $<$ http://www. iff.sc.gov.br>, Vibrans et al. 2010) have covered the entire state of $\mathrm{SC}$ with a systematic sampling.

In this study we have aimed to present the current species composition of the Evergreen Rainforest recorded by IFFSC with reference to their ecological traits such as dispersal syndromes, ecological group, and historical records.

\section{Material and Methods}

\section{Species data}

We obtained species data from the Floristic and Forest Inventory of Santa Catarina (IFFSC) in the area covered by Evergreen Rainforest (see Vibrans et al. 2010 for more details about

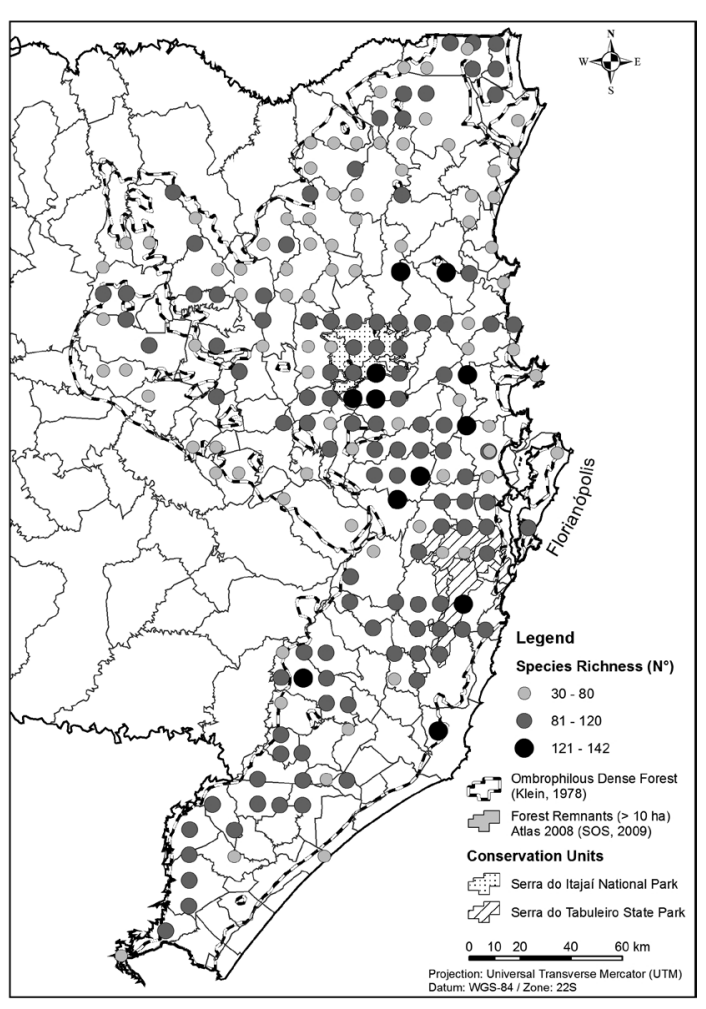

Figure 1 - Sample units from Evergreen Rainforest (ERF) in Santa Catarina state.

sampling design and methods). We included the vascular plants recorded in 202 permanent plots (Fig. 1), systematically distributed over a $10 \times 10 \mathrm{~km}$ grid as proposed by IFFSC, with 72 ha of total sampled area. All sampled units are located in Evergreen Rainforest, according to Klein (1978). The vegetation classification follows Oliveira-Filho (2009); 34 sampled units were classified as belonging to subtropical lower plains, 89 to subtropical upper plains, 73 to subtropical lower highlands and six to subtropical upper highlands. Five of the sample units were installed in conservation units outside the grid, using the same sampling methods described in Vibrans et al. (2010). The sampling effort was different among the component: (1) tree/shrub: individuals with diameter at breast height $(\mathrm{DBH}) \geq 10 \mathrm{~cm}$ in an area of $4,000 \mathrm{~m}^{2}$; (2) regeneration: individuals with $\mathrm{DBH}<10 \mathrm{~cm}$ and height $\geq 50 \mathrm{~cm}$ in an area of $400 \mathrm{~m}^{2}$; and (3) floristic survey: fertile plants collected within and around the sample units, even outside the criteria listed above, as well as on the access way to the sample units. 
The species of components 1 and 2 were also classified in relation to (a) ecological group: pioneer, secondary and climax, according to information available in the literature (Reitz 1965; Reitz et al. 1979; Klein 1990), and the field experience of the IFFSC team; (b) seed dispersal mode: anemochoric, zoochoric, and autochoric, following Van der Pijl (1982). The classifications were based on detailed accounts of species life form traits available in the literature (e.g. Reitz 1965; Reitz et al. 1979; Klein 1990; Vibrans et al. 2012a, 2012b, 2013b, 2013c) or based on the authors' knowledge about species' traits. We indicated all species categorized as threatened according to IUCN (2014), Red Book of Brazilian Flora (Martinelli \& Moraes 2013) and MMA (2008).

Only individuals identified at species or genus level were considered in the analysis. When identified at generic level, we included the species in our accounts only if the genus had not yet been cited, in order to avoid overestimation. As we sampled almost 14,000 fertile plants from the component 3 , and little more than 11,000 sterile plants from the components 1 and 2, it was not possible to identify all the samples to specific or morphospecies level, and then, we used the aforementioned criteria. Exotic species were excluded of the list (for more details about exotic species see Meyer et al. 2012). We adopted classification system APG III (2009) for the angiosperms, with adaptation for the family Peraceae (Davis et al. 2007; Souza \& Lorenzi 2012; Nikolov et al. 2013); Smith et al. (2006), with adaptation from Rothfels et al. (2012) for ferns, Ollgard (2012) for lycophytes, and Christenhusz et al. (2011) for gymnosperms. The spelling of the names followed the List of Species of the Brazilian Flora (2014).

\section{Results}

We recorded 1,473 species, consisting of three gymnosperms and 1,470 angiosperms, belonging to 599 genera and 144 botanical families (Tab. 1 and appendix 1 in online version). For the tree-shrub component, we found 567 species, 16 of which are exclusively found in this component. Within the regeneration component, we recorded 635 species, 13 of which exclusive to this component. Moreover, we recorded 1,406 species in the floristic survey component; 750 of these were registered exclusively in this component (Fig. 2). The minimum and maximum species richness values found per sample unit for the tree-shrub and regeneration components were 30 and 142 (Fig. 1). We found 663 species in the Subtropical Lower Plains, 1,066 in the Upper Plains, 1090 in the Lower Highlands and 288 in the Upper Highlands.

The richest families in species were Orchidaceae (143 species), Myrtaceae (142), Asteraceae (98), Melastomataceae (86), Fabaceae (78), Rubiaceae (65), Solanaceae (61), Bromeliaceae (57), Piperaceae (56), and Lauraceae (52). We found 55 families represented by a single species (See appendix 1 in online version).

We found eight endangered species (MMA 2008, Tab. 2): Aechmea blumenavii, Araucaria angustifolia, Billbergia alfonsijoannis, Euterpe edulis, Heliconia farinosa, Ocotea catharinensis, $O$. odorifera, and $O$. porosa. Moreover, another 43 species were listed in the Red Book of the Brazilian Flora (Martinelli \& Moraes 2013), being 23 endangered (EN) and 20 vulnerable (VU). We found 38 of the 128 species listed by the IUCN Redlist (2014) for Santa Catarina (Tab. 2), being eight near threatened (LR/nt), four conservation dependent (LR/cd), 13 least concern (LC), eight vulnerable (VU), four endangered (EN) and one critically endangered (CR).

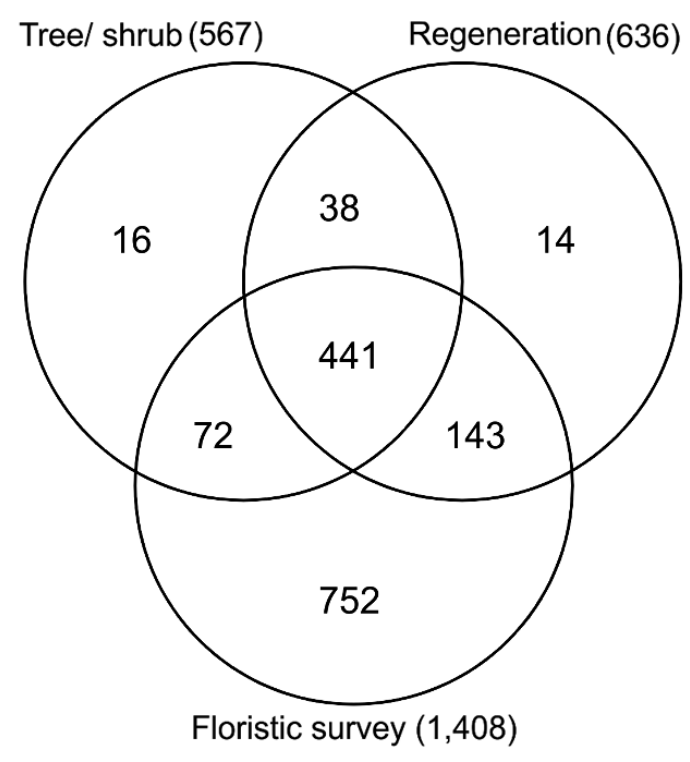

Figure 2 - Venn diagram representing the sampled and shared species in each component (tree-shrub, regeneration and floristic survey). 
Table 1 - Summary of floristic species surveys sampled within the Evergreen Rainforest through the Floristic and Forest Inventory of Santa Catarina State.

\begin{tabular}{lc}
\hline Category & Number \\
\hline Families & 144 \\
Genus & 599 \\
Species & 1,473 \\
Gymnosperms species & 3 \\
Angiosperms species & 1,470 \\
Species in tree/shrub component & 567 \\
Species in regeneration component & 635 \\
Species in floristic survey & 1,406 \\
component & 8 \\
Endangered species (MMA 2008) & \\
Endangered species (Martinelli \& & 43 \\
Moraes 2013) & 38 \\
Endangered species (IUCN 2014) & 3 \\
\hline
\end{tabular}

Of the 723 species of the tree-shrub and regeneration components, $78.0 \%$ were zoochoric, $14.8 \%$ were anemochoric, and $6.8 \%$ were autocoric; we classified $21.4 \%$ as pioneer, $48.4 \%$ as secondary, and $20.4 \%$ as climax species (See appendix 2 in online version). Due to lack of information, $0.4 \%$ and $9.8 \%$ of species were not classified regarding their dispersion syndrome and ecological group, respectively.

Phanerophytes (trees and shrubs) accounted for $58.7 \%$ of the species, followed by terrestrial herbs $(18.9 \%)$, epiphytes $(15.6 \%)$, rupicolous $(3.6 \%)$, climbers $(9.8 \%)$, and hydrophytes and parasites $(0.6 \%)$. Among the parasites there were holoparasityes such as Balanophoraceae (Helosis cayennensis, Langsdorffia hypogaea) or mistletoes, belonging to Loranthaceae (Struthanthus polyrhizus, S. vulgaris, Tripodanthus acutifolius) and Santalaceae (Phoradendron chrysocladon, P. crassifolium and $P$. ensifolium). It is important to emphasize that climbers, rupicolous, parasites, and hydrophytes were assessed occasionally (when fertile) and not systematically as trees and shrubs.

\section{Discussion}

According to our results, we found $19 \%$ of the vascular species listed to accour in Brazilian Evergreen Rainforest by Stehmann et al. (2009). The high species richness found here also shows the importance of our floristic survey since such a large number of species (752) was recorded only in this type of sampling. The collected specimens account for about 8,315 records in the FURB Herbarium. These data represent an important source of information (Funk et al. 2005), available online to researchers for multiple purposes, such as conducting studies on geographic distribution modeling, DNA samples, or population studies. In similar work, Gasper et al. (2013a, 2013b) found 925 species in Santa Catarina Mixed Forest and 420 in Seasonal Semideciduous Forest, numbers that together do not reach the diversity sampled here for the Evergreen Rainforest. The most abundant treeshrub families in Santa Catarina are Asteraceae, Myrtaceae, Fabaceae, and Melastomataceae (Gasper et al. 2012), the same of this work. These comparative data appear to support the strong differences between the hinterland forests and the coastal forests noted by other authors such as Oliveira-Filho et al. (2006) and Oliveira-Filho et al. (2013). The latter state that, while the differences between the coastal forests and the hinterland forests in the tropical zone are due to differences in the annual distribution of rainfall, in the subtropics temperature contrasts are more important, probably because many of the species do not tolerate the cold and frosts that happen periodically in continental climates.

In spite of the high species richness mentioned above, there are at least 150 angiosperm species that were not found during the present survey (most of them phanerophytes) and that were formerly recorded in the Itajaí-Açu watershed Valley (SC) by Klein $(1979,1980)$. Most of these species have been reported as rare or very rare by the same author. Therefore, these results support the notion that these species are rare, given the large sampling effort applied by IFFSC. Moreover, it seems rather apparent that the methodology did not satisfactorily cover riparian zones, so that some species were not recorded, such as rheophyte Raulinoa echinata R.S.Cowan, Dyckia ibiramensis Reitz, Dalechampia riparia L.B.Sm. \& Downs, endemic to a small area in the Itajaí-Açu watershed (Reitz 1983). On the other hand, the presence of species often related to Mixed Forest, such as Araucaria angustifolia, is due to ecotones within the sampling areas.

Of the eight endangered species, $A$. angustifolia, $O$. catharinensis, $O$. odorifera, and $O$. porosa fall into this category due to intense 
Table 2 - Endangered species according the IUCN Red List of Threatened Species (IUCN 2014), the Red Book of Brazilian Flora (Martinelli \& Moraes 2013), and the Official List of Endangered Species of the Brazilian Flora (MMA 2008). CR: Critically endangered; EN: Endangered; LC: Least concern; LR/cd: Lower risk/conservation dependent; LR/nt: Lower risk/near threatened; VU: Vulnerable.

\begin{tabular}{|c|c|c|c|}
\hline Endangered species & IUCN (2014) & Martinelli \& Moraes (2013) & MMA (2008) \\
\hline Aechmea blumenavii & & & $x$ \\
\hline Aechmea kertesziae & & EN & \\
\hline Andira fraxinifolia & $\mathrm{LC}$ & & \\
\hline Araucaria angustifolia & $\mathrm{CR}$ & EN & $\mathrm{x}$ \\
\hline Asplundia polymera & & VU & \\
\hline Aureliana fasciculata & $\mathrm{LR} / \mathrm{cd}$ & & \\
\hline Balfourodendron riedelianum & EN & & \\
\hline Bauhinia forficata & $\mathrm{LC}$ & & \\
\hline Begonia per-dusenii & & EN & \\
\hline Begonia stenolepis & & EN & \\
\hline Billbergia alfonsijoannis & & & $\mathrm{x}$ \\
\hline Brosimum glaziovii & EN & & \\
\hline Buchenavia kleinii & $\mathrm{LR} / \mathrm{nt}$ & & \\
\hline Calyptranthes hatschbachii & & EN & \\
\hline Calyptranthes pileata & & VU & \\
\hline Campomanesia reitziana & $\mathrm{LR} / \mathrm{nt}$ & VU & \\
\hline Cattleya intermedia & & VU & \\
\hline Cedrela fissilis & EN & VU & \\
\hline Chionanthus filiformis & $\mathrm{LR} / \mathrm{nt}$ & & \\
\hline Chrysophyllum inornatum & $\mathrm{LR} / \mathrm{cd}$ & & \\
\hline Chrysophyllum viride & $\mathrm{LR} / \mathrm{nt}$ & & \\
\hline Cinnamomum hatschbachii & & VU & \\
\hline Dendrophorbium catharinense & & VU & \\
\hline Epidendrum proligerum & $\mathrm{LC}$ & & \\
\hline Eugenia imaruiensis & & EN & \\
\hline Eugenia malacantha & & $\mathrm{EN}$ & \\
\hline Eugenia neotristis & & EN & \\
\hline Eugenia pruinosa & & EN & \\
\hline Eugenia sclerocalyx & & VU & \\
\hline Euterpe edulis & & VU & $\mathrm{x}$ \\
\hline Grandiphyllum divaricatum & & VU & \\
\hline Grandiphyllum hians & & VU & \\
\hline Habenaria parviflora & $\mathrm{LC}$ & & \\
\hline Hatiora gaertneri & VU & & \\
\hline Heliconia farinosa & $\mathrm{LC}$ & & $\mathrm{x}$ \\
\hline
\end{tabular}




\begin{tabular}{|c|c|c|c|}
\hline Endangered species & IUCN (2014) & Martinelli \& Moraes (2013) & MMA (2008) \\
\hline Ilex paraguariensis & $\mathrm{LR} / \mathrm{nt}$ & & \\
\hline Inga lentiscifolia & VU & & \\
\hline Leandra hatschbachii & & $\mathrm{EN}$ & \\
\hline Lepismium cruciforme & $\mathrm{LC}$ & & \\
\hline Lepismium houlletianum & $\mathrm{LC}$ & & \\
\hline Lobelia langeana & & $\mathrm{EN}$ & \\
\hline Malaxis jaraguae & & VU & \\
\hline Manilkara subsericea & $\mathrm{LR} / \mathrm{cd}$ & & \\
\hline Mimosa bimucronata & $\mathrm{LC}$ & & \\
\hline Mollinedia eugeniifolia & & $\mathrm{EN}$ & \\
\hline Mollinedia luizae & & VU & \\
\hline Myrceugenia bracteosa & & $\mathrm{EN}$ & \\
\hline Myrceugenia foveolata & & $\mathrm{EN}$ & \\
\hline Myrceugenia hoehnei & & VU & \\
\hline Myrceugenia kleinii & & VU & \\
\hline Myrcia diaphana & & VU & \\
\hline Myrcia rupicola & & EN & \\
\hline Myrciaria plinioides & & VU & \\
\hline Neomitranthes cordifolia & VU & VU & \\
\hline Ocotea catharinensis & VU & VU & $\mathrm{x}$ \\
\hline Ocotea odorifera & & EN & $\mathrm{x}$ \\
\hline Ocotea porosa & VU & EN & $\mathrm{x}$ \\
\hline Plinia edulis & & VU & \\
\hline Podocarpus lambertii & $\mathrm{LR} / \mathrm{nt}$ & & \\
\hline Podocarpus sellowii & EN & & \\
\hline Renealmia brasiliensis & & $\mathrm{EN}$ & \\
\hline Rhipsalis campos-portoana & $\mathrm{LC}$ & & \\
\hline Rhipsalis elliptica & $\mathrm{LC}$ & & \\
\hline Rhipsalis floccosa & $\mathrm{LC}$ & & \\
\hline Rhipsalis pachyptera & $\mathrm{LC}$ & & \\
\hline Rhipsalis puniceodiscus & $\mathrm{LC}$ & & \\
\hline Roupala asplenioides & & $\mathrm{EN}$ & \\
\hline Solanum bullatum & $\mathrm{LR} / \mathrm{cd}$ & & \\
\hline Solanum pinetorum & $\mathrm{LR} / \mathrm{nt}$ & & \\
\hline Symplocos corymboclados & & $\mathrm{EN}$ & \\
\hline Terminalia reitzii & VU & & \\
\hline Trichilia casaretti & VU & & \\
\hline Trichilia pallens & $\mathrm{LR} / \mathrm{nt}$ & & \\
\hline
\end{tabular}




\begin{tabular}{lccc}
\hline Endangered species & IUCN (2014) & Martinelli \& Moraes (2013) & MMA (2008) \\
\hline Trichilia silvatica & VU & & \\
Verbenoxylum reitzii & & EN & \\
Virola bicuhyba & & EN & \\
Wittrockia superba & & EN & \\
\hline
\end{tabular}
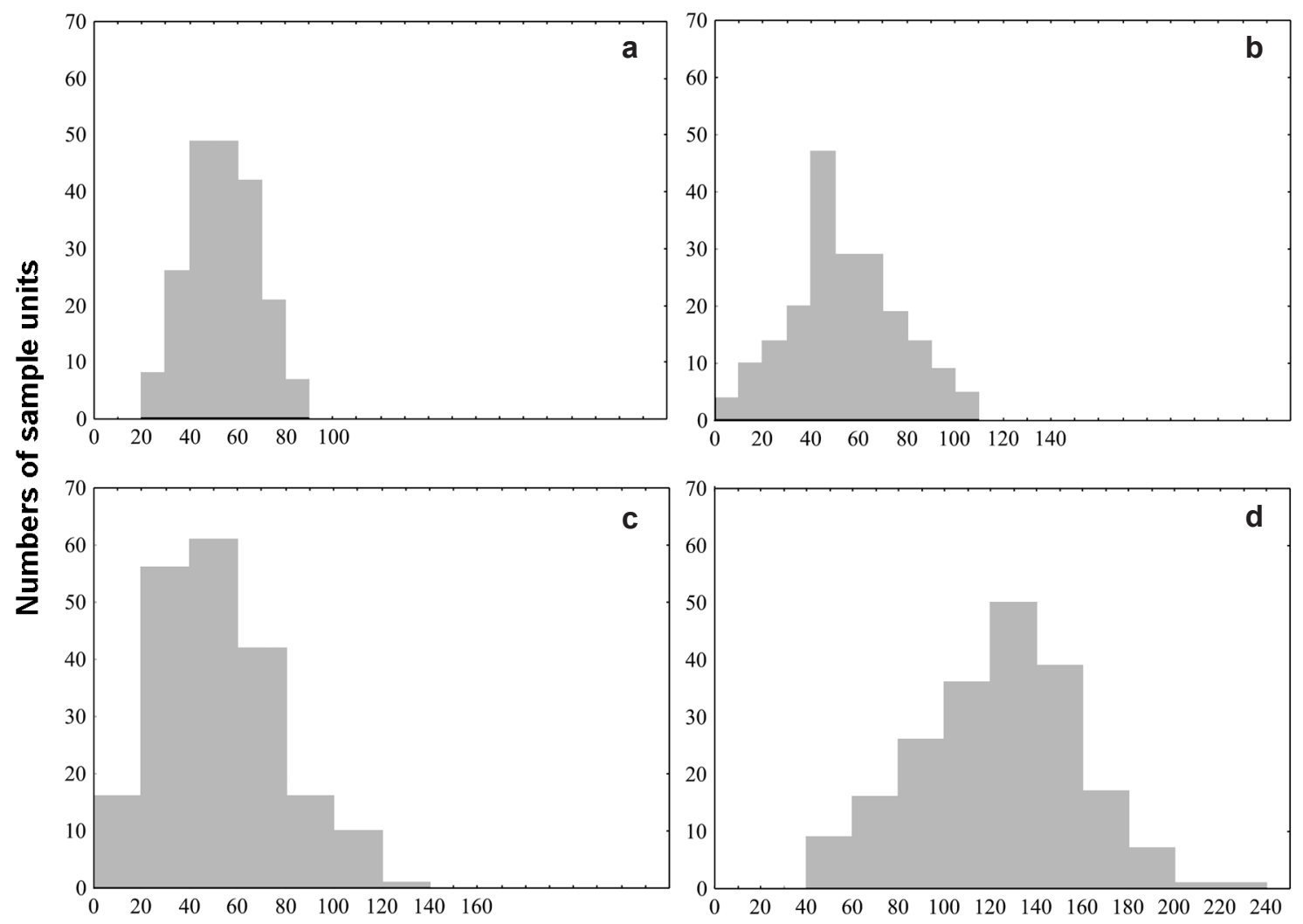

Richness / sample units

Figure 3 - Frequency distribution of the richness in the subplots distributed in Evergreen Rainforest (ERF). a. treeshrub component; b. regeneration; c. floristic survey; d. total.

exploitation of their valuable timber; $O$. odorifera has also been the target of essential oil extraction (Reitz et al. 1979; Martinelli \& Moraes 2013). Euterpe edulis is threatened by the intense extraction of palm heart, used in the regional cuisine (Reis et al. 1996; Fernandes 2000). Apart from the exploitation of these species, habitat loss caused by deforestation and fragmentation led to population shrinkage and high risk of extinction (Martinelli \& Moraes 2013).

In conserved tropical forests, often $75 \%$ or more of the species are zoochoric (Howe \& Smallwood 1982). However, the percentage of each dispersal type varies in relation to the vegetation type, with an expected higher proportion of animal-dispersed species in moist environments, while anemochoric and autochoric species are more abundant in environments with reduced precipitation and increased seasonality (Silva \& Rodal 2009). We found $78 \%$ of zoochoric dispersal, the percentage that was expected since the Evergreen Rainforest is the best conserved forest type of Santa Catarina and the climatic conditions are favorable for this type of dispersal. The successional stage also influences the occurrence of different dispersion strategies, hence 
forest remnants in advanced regeneration or primary stages usually have a higher number of zoochoric species (Howe \& Smallwood 1982; Tabarelli \& Peres 2002). For the Evergreen Rainforest of Santa Catarina, it seems that the successional stages are clearly linked to the ratio of dispersal syndromes. However, the percentage of zoochoric species corroborates what is expected for tropical forests and what has been found in other studies (Carvalho 2010; Lima et al. 2011.). The proportion of each syndrome may change with the regeneration dynamic, but is also subject to anthropogenic pressures such as selective logging and hunting (Tabarelli \& Peres 2002).

There was an uneven distribution of biodiversity throughout the study area (Fig. 1 and 3 ). Some of the richest areas were located around protected areas such as the Parque Nacional da Serra do Itajaí and Parque Estadual do Tabuleiro; land use policies in their vicinity could induce the spreading of viable populations of these species from inside the protected areas to their currently impoverished surroundings.

\section{Conclusion}

The methodical floristic sampling of Evergreen Rainforest by IFFSC is the first of its kind performed in the country and has demonstrated the importance of systematic and unbiased sampling. It also recorded that species richness sampling considerably increases by recording/ collecting fertiles specimens outside sample plots primarily used to assess forest structure. The study proved that Santa Catarina is a vascular plant diversity hotspot within the Atlantic Forest domain. As a systematic assessment, the present study did not sample special habitats like smallscale riparian vegetation, which must be sampled as a complement to this data-set.

\section{References}

APG. 2009. An update of the Angiosperm Phylogeny Group classification for the orders and families of flowering plants: APG III. Botanical Journal of the Linnean Society 161: 105-121.

Carvalho, F.A. 2010. Síndromes de dispersão de espécies arbóreas de florestas ombrófilas submontanas do estado do Rio de Janeiro. Revista Árvore 34: 1017-1023.

Christenhusz, M.J.M.; Reveal, J.L.; Farjon, A.; Gardner, M.F.; Mill, R.R. \& Chase, M.W. 2011. A new classification and linear sequence of extant gymnosperms. Phytotaxa 19: 55-70.
Citadini-Zanette, V.; Soares, J.J. \& Martinello, C.M. 1997. Lianas de um remanescente florestal da microbacia do Rio Novo, Orleans, Santa Catarina, Brasil. Insula 26: 45-63.

Colonetti, S.; Citadini-Zanette, V.; Martins, R.; Santos, R.; Rocha, E. \& Jarenkow, J.A. 2009. Florística e estrutura fitossociológica em floresta ombrófila densa submontana na barragem do rio São Bento, Siderópolis, estado de Santa Catarina. Acta Scientiarum 31: 397-405.

Davis, C.C.; Latvis, M.; Nickrent, D.L.; Wurdack, K.J. \& Baum, D.A. 2007. Floral gigantism in Rafflesiaceae. Science 315: 1812.

Falkenberg, D.B. 1999. Aspectos da flora e da vegetação secundária da restinga de Santa Catarina, Sul do Brasil. Insula 28: 1-30.

Fernandes, I. 2000. Taxonomia dos representantes de Dicksoniaceae no Brasil. Pesquisas Botânica 50: 5-26.

Funk, V.A.; Hoch, P.C.; Prather, L.A. \& Wagner, W.L. 2005. The importance of vouchers. Taxon 54: 127-129.

Gasper, A.L.; Meyer, L.; Sevegnani, L.; Sobral, M. \& Bonnet, A. 2012. Flora vascular de Santa Catarina uma síntese do inventário florístico florestal de Santa Catarina. In: Vibrans, A.C.; Sevegnani, L.; Gasper, A.L. \& Lingner, D.V. (orgs.). Inventário Florístico Florestal de Santa Catarina. Vol. 1. Diversidade e conservação dos remanescentes florestais. Edifurb, Blumenau. Pp. 99-111.

Gasper, A.L.; Sevegnani, L.; Vibrans, A.C.; Sobral, M.; Uhlmann, A.; Lingner, D.V.; Rigon-Júniro, M.J.; Verdi, M.; Stival-Santos, A.; Dreveck, S. \& Korte, A. 2013a. Inventário florístico florestal de Santa Catarina: espécies da Floresta Ombrófila Mista. Rodriguésia 64: 201-210.

Gasper, A.L.; Uhlmann, A.; Sevegnani, L.; Lingner, D.V.; Rigon-Júnior, M.J.; Verdi, M.; Stival-Santos, A.; Dreveck, S.; Sobral, M. \& Vibrans, A.C. 2013b. Inventário florístico florestal de Santa Catarina: espécies da Floresta Estacional Decidual. Rodriguésia 64: 427-443.

Howe, H.F. \& Smallwood, J. 1982. Ecology of seed dispersal. Annual Review of Ecology and Systematics 13: 201-28.

IBGE. 1992. Manual técnico da vegetação brasileira. IBGE, Rio de Janeiro

IUCN 2014. The IUCN Red List of Threatened Species. Version 2014.2. Available in $<$ http://www. iucnredlist.org >. Access on 24 July 2014.

Joly, C.A.; Aidar, M.P.M.; Klink, C.A.; McGrath, D.G.; Moreira, A.G.; Moutinho, P.; Nepstad, D.C.; Oliveira, A.A.; Pott, A.; Rodal, M.J.N. \& Sampaio, E.V.S.B. 1999. Evolution of the Brazilian phytogeography classification systems: implications for biodiversity conservation. Ciência \& Cultura 51: 331-348. 
Klein, A.S.; Citadini-Zanette, V. \& Santos, R. 2007. Florística e estrutura comunitária de restinga herbácea no município de Araranguá, Santa Catarina. Biotemas 20: 15-26.

Klein, R.M. 1978. Mapa fitogeográfico do estado de Santa Catarina. In: Reitz, R. (ed.). Flora ilustrada catarinense. Herbário Barbosa Rodrigues, Itajaí. 24p.

Klein, R.M. 1979. Ecologia da flora e vegetação do Vale do Itajaí. Sellowia 31: 1-164.

Klein, R.M. 1980. Ecologia da flora e vegetação do Vale do Itajaí (continuação). Sellowia 32: 165-389.

Klein, R.M. 1990. Espécies raras ou ameaçadas de extinção do estado de Santa Catarina. IBGE, Rio de Janeiro. 282p.

Klein, R.M.; Bresolin, A. \& Reis, A. 1978. Distribuição de orquídeas da Ilha de Santa Catarina. Insula 9: 3-29.

Leite, P.F. \& Klein, R.M. 1990. Geografia do Brasil. Vol. 2. IBGE, Rio de Janeiro. 420p.

Leite, P.F. 2002. Contribuição ao conhecimento fitoecológico do Sul do Brasil. Ciências \& Ambiente 13: 51-73.

Lima, M.E.L.; Cordeiro, I. \& Moreno, P.R.H. 2011. Estrutura do componente arbóreo em Floresta Ombrófila Densa Montana no Parque Natural Municipal Nascentes de Paranapiacaba (PNMNP), Santo André, SP, Brasil. Hoehnea 38: 73-96.

List of Species of the Brazilian Flora. 2014. Available in <http://floradobrasil.jbrj.gov.br/>. Access on 15 February 2014.

Martinelli, G. \& Moraes, M.A. 2013. Livro vermelho da flora do Brasil. Instituo de Pesquisas Jardim Botânico do Rio de Janeiro, Rio de Janeiro. 1100p.

Martinelli, G. 2007. Mountain biodiversity in Brazil. Brazilian Journal of Botany 30: 587-597.

Meyer, L.; Vibrans, A.C.; Gasper, A.L.; Lingner, D.V. \& Sampaio, D.K. 2012. Espécies exóticas encontradas nas florestas de Santa Catarina. In: Vibrans, A.C.; Sevegnani, L.; Gasper, A.L. \& Lingner, D.V. (org.). Inventário florístico florestal de Santa Catarina. Vol. 1. Diversidade e conservação dos remanescentes florestais. Edifurb, Blumenau. Pp. 193-215.

MMA - Ministério do Meio Ambiente. 2008. Espécies da flora brasileira ameaçadas de extinção. Instrução normativa n.6, de 23 de setembro de 2008.

Morellato, L.P.C. \& Haddad, C.F.B. 2000. Introduction: The Brazilian Atlantic Forest. Biotropica 32: 786-792.

Negrelle, R.R.B. 2006. Composição florística e estrutura vertical de um trecho de Floresta Ombrófila Densa de Planície Quaternária. Hoehnea 33: 261-289.

Neves, B.T. \& Zanin, A. 2011. Sinopse das espécies nativas e subespontâneas de Andropogoneae Dumort. (Poaceae) na Ilha de Santa Catarina, Brasil. Acta Botanica Brasilica 25: 916-928.
Nikolov, L.A.; Endress, P.K.; Sugumaran, M.; Sasirat, S.; Vessabutr, S.; Kramer, E.M. \& Davis, C.C. 2013. Developmental origins of the world's largest flowers, Rafflesiaceae. PNAS 110: 18578-18583.

Oliveira-Filho, A.T. \& Fontes, M.A.L. 2000. Patterns of floristic differentiations among Atlantic Forests in southeastern Brazil and the influence of climate. Biotropica 32: 793-810.

Oliveira-Filho, A.T.; Budke, J.C.; Jarenkow, J.A.; Eisenlohr, P.V. \& Neves, D.R.M. 2013. Delving into the variations in tree species composition and richness across South American subtropical Atlantic and Pampean forests. Journal of Plant Ecology (in press).

Oliveira-Filho, A.T.; Jarenkow. J.A. \& Rodal, M.J.N. 2006. Floristic relationships of seasonally dry forests of eastern South America based on tree species distribution patterns. In: Pennington, R.T.; Ratter, J.A. \& Lewis, G.P. (eds.). Neotropical savannas and dry forests: Plant diversity, biogeography and conservation. CRC Press, Boca Raton. Pp. 159-19.

Øllgaard, B. 2012. Nomenclatural changes in Brazilian Lycopodiaceae. Rodriguésia 63: 479-482.

Reis, A.; Kageyama, P.Y.; Reis, M.S.R. \& Fantini, A. 1996. Demografia de Euterpe edulis Martius (Arecaceae) em uma Floresta Ombrófila Densa Montana, em Blumenau, SC. Sellowia 45-48: 13-45.

Reitz, R. 1965. Plano de coleção. In: Reitz, R. (ed.). Flora ilustrada catarinense. Herbário Barbosa Rodrigues, Itajaí. 71p.

Reitz, R. 1983. Bromeliáceas e a malária-bromélia endêmica. In: Reitz, R. (ed.). Flora ilustrada catarinense. Herbário Barbosa Rodrigues, Itajaí. 518p.

Reitz, R.; Klein, R.M. \& Reis, A. 1979. Madeiras do Brasil. Lunardelli, Florianópolis. 320p.

Rothfels, C.J.; Sundue, M.A.; Kuo, L.Y.; Larsson, A. \& Kato, M. 2012. A revised family-level classification for eupolypod II ferns (Polypodiidae: Polypodiales). Taxon 61: 515-533.

Silva, M.C.N.A. \& Rodal, M.J.N. 2009. Padrões das síndromes de dispersão de plantas em áreas com diferentes graus de pluviosidade, PE, Brasil. Acta Botanica Brasilica 23: 1040-1047.

Smith, A.R.; Pryer, K.M.; Schuettpelz, E.; Korall, P.; Schneider, H. \& Wolf, P.G. 2006. A classification for extant ferns. Taxon 55: 705-731.

Souza, V.C. \& Lorenzi, H. 2012. Botânica sistemática: guia ilustrado para identificação das famílias de fanerógamas nativas e exóticas no Brasil, baseado em APG III. $3^{\text {a }}$ ed. Instituto Plantarum, Nova Odessa. 768p.

Stehmann, J.R.; Forzza, R.C.; Salino, A.; Sobral, M.; Costa, D.P. \& Kamino, L.H.Y. 2009. Plantas da Floresta Atlântica. Instituto de Pesquisas Jardim Botânico do Rio de Janeiro, Rio de Janeiro. 516p. 
Tabarelli, M. \& Peres, C.A. 2002. Abiotic and vertebrate seed dispersal in Brazilian Atlantic Forest: implications for forest regeneration. Biological Conservation 106: 165-176.

Van der Pijl, L. 1982. Principles of dispersal in higher plants. $3^{\text {rd }}$ ed. Springer-Verlag, Berlin. 214p.

Veloso, H.P. \& Klein, R.M. 1957. As comunidades e associações vegetais da mata pluvial do sul do Brasil. I-As comunidades do município de Brusque, estado de Santa Catarina. Sellowia 9: 81-235.

Veloso, H.P. \& Klein, R.M. 1959. As comunidades e associações vegetais da mata pluvial do sul do Brasil. II - Dinamismo e fidelidade das espécies em associações do Município de Brusque, Estado de Santa Catarina. Sellowia 10: 9-124.

Veloso, H.P. \& Klein, R.M. 1961. As comunidades e a associações vegetais da mata pluvial do sul do Brasil: As associações das planícies costeiras do quaternário, situadas entre o rio Itapocu (estado de Santa Catarina) e a bacia do Paranaguá (estado do Paraná). Sellowia 13: 205-260.

Veloso, H.P. \& Klein, R.M. 1963. As comunidades e associações vegetais da mata pluvial do sul do Brasil. IV - As associações situadas entre o rio Tubarão e a lagoa dos Barros. Sellowia 15: 57-114.

Veloso, H.P. \& Klein, R.M. 1968a. As comunidades e associações vegetais da mata pluvial do sul do Brasil. V - Agrupamentos arbóreos da encosta catarinense situados em sua parte norte. Sellowia 20: 53-126.

Veloso, H.P. \& Klein, R.M. 1968b. As comunidades e associações vegetais da mata pluvial do sul do
Brasil. VI - Agrupamentos arbóreos dos contrafortes da Serra Geral situados aos sul da costa catarinense e ao norte da costa sul-riograndense. Sellowia 20: 127-180.

Vibrans, A.C.; McRoberts, R.E.; Moser, P. \& Nicoletti, A. 2013a. Using satellite image-based maps and ground inventory data to estimate the remaining Atlantic forest in the Brazilian state of Santa Catarina. Remote Sensing of Environment 130: 87-95.

Vibrans, A.C.; Sevegnani, L.; Gasper, A.L. \& Lingner, D.V. 2012a. Inventário Florístico Florestal de Santa Catarina. Vol. 1. Diversidade e conservação dos remanescentes florestais. Edifurb, Blumenau. 344p.

Vibrans, A.C.; Sevegnani, L.; Gasper, A.L. \& Lingner, D.V. 2012b. Inventário florístico florestal de Santa Catarina. Vol. 2. Floresta Estacional Decidual. Edifurb, Blumenau. 336p.

Vibrans, A.C.; Sevegnani, L.; Gasper, A.L. \& Lingner, D.V. 2013b. Inventário florístico florestal de Santa Catarina. Vol. 3. Floresta Ombrófila Mista. Edifurb, Blumenau. 440p.

Vibrans, A.C.; Sevegnani, L.; Gasper, A.L. \& Lingner, D.V. 2013c. Inventário Florístico Florestal de Santa Catarina. Vol. 4. Floresta Ombrófila Densa. Edifurb, Blumenau. 576p.

Vibrans, A.C.; Sevegnani, L.; Lingner, D.V.; Gasper, A.L. \& Sabbagh, S. 2010. Inventário florístico florestal de Santa Catarina (IFFSC): aspectos metodológicos e operacionais. Pesquisa Florestal Brasileira 30: 291-302.

Waechter, J.L. 2002. Padrões geográficos na flora atual do Rio Grande do Sul. Ciência \& Ambiente 24: 93-108. 